\title{
A Systematic Review on Entrepreneurship Education in Higher Learning Institutions in Southeast Asia
}

\author{
Nor Hafiza Othman ${ }^{1,2, *}$, Norasmah Othman ${ }^{1}$ \\ ${ }^{1}$ Faculty of Education, Universiti Kebangsaan Malaysia, Malaysia \\ ${ }^{2}$ Faculty of Business and Entrepreneurship, Universiti Malaysia Kelantan, Malaysia \\ Received September 7, 2019; Revised October 10, 2019; Accepted October 17, 2019
}

Copyright $\bigcirc 2019$ by authors, all rights reserved. Authors agree that this article remains permanently open access under the terms of the Creative Commons Attribution License 4.0 International License

\begin{abstract}
Many countries have invested in entrepreneurship education through programs and trainings especially in the Higher Learning Institutions (HLIs). This paper aims to systematically review the outcome of entrepreneurship education (EE) in the higher learning education by reviewing the latest ten-year published records in Southeast Asian countries. The study's primary source of data were research articles published from 2009 to 2018 in English written peer-reviewed journals on Web of Science and Scopus database. A total of 68 related articles were identified, and most of them were Malaysian articles, followed by the Indonesian's. A systematic review approach was applied, guided by the PRISMA Statement, whereby the current study showed the existence of the EE research trend, especially in higher learning institutions. Besides that, this study also shows the outcome of EE in sixth themes, entrepreneurial attitude, entrepreneurial skills and knowledge, entrepreneurial motivation, entrepreneurial competency, entrepreneurial intention, and business start-up. The outcome of entrepreneurship education could be seen more visibly whether it has a positive effect or otherwise, in developing the potential of students as entrepreneurs.
\end{abstract}

Keywords Entrepreneurship Education, Higher Learning, Southeast Asia, Impact

\section{Introduction}

Entrepreneurship Education (EE) is emerging very rapidly. The early history of the introduction of EE in Higher Learning Institutions (HLIs) was implemented in 1968 when Babson College offered entrepreneurship courses to undergraduate students (Katz, 2003). Then, in 1974, the Harvard Business School offered entrepreneurship courses for Master of Business Administration (MBA) students (Bechard \& Gregoire,
2005). In 1982, EE in higher learning was becoming increasingly popular after the University of Southern California offered it in 1971, and now, the number of colleges and universities that offer the course have exceeded 3000 worldwide (Kuratko \& Morris, 2017). The EE can provide entrepreneurs and potential entrepreneurs with knowledge, skills and attitudes needed to deal with the pressures, challenges and uncertainties in the environment (Dumitrache \& Raileanu, 2014; Othman et al., 2012). Therefore, the government places emphasis on creating awareness of the importance of entrepreneurs for all education levels, especially in HLIs and hence choosing entrepreneurship as a career option.

The implementation of EE is created through development of curriculum and entrepreneurial learning activities whether formal or informal. This indicates that HLIs play important roles in ensuring EE to be able to develop the potentials of students and raise their awareness and thinking to become entrepreneurs. Experiential learning is an effective way for educational institutions to influence student entrepreneurial behavior and conduct business activities on campus. This is parallel to Fayolle and Gailly (2008) who stated that to encourage and inculcate entrepreneurship-oriented students, they should be exposed to entrepreneurial activities. This was acknowledged by Hamzah et al. (2016) who found that a compulsory entrepreneurship course in a public university in Malaysia can affect entrepreneurial intentions among graduates of a real estate programme.

However, studies conducted by Karimi et al. (2014) showed that the ability of students in applying ideas and exploring business opportunities was still low. This is consistent with a study conducted by Gutierrez and Baquero (2017), who found that the lack of exposures to EE in Spain had resulted in 80 per cent failures in new business ventures within the first five years, while the new companies in Mexico showed that 75 percent new entrepreneurs were no longer running their companies in the third year. This situation illustrates the influence of 
entrepreneurship education in developing the potentials of entrepreneurs in HLIs in assessing potential opportunities in the environment should be further elaborated. This was acknowledged by Fayolle (2013) who mentioned that previous studies that see directly on the learning outcomes of EE were very scarce. Therefore, this review is important to understand the outcome of entrepreneurship education studies that were conducted before.

The systematic review is an analysis of the formulated research question that uses a systematic method to collect secondary data and attempts to identify, select and synthesize studies to answer a given research question. To build a relevant systematic review, the current articles were guided by a main research question - what is the outcome of EE in HLIs in Southeast Asia? The main focus of this study is to explore the outcome of EE in HLIs. This article also attempts to identify the most outcome of EE by scholars in the last 10 years. Therefore, this article aims to systematically review the outcome of EE in HLIs by reviewing ten-year-corpus of related published records in Southeast Asian countries.

This part describes the purpose of carrying out this systematic research. The second part discusses about the methodology and approach of Preferred Reporting Systematic Reviews and Meta-Analysis (PRISMA) Statement that were used. These are followed by systematic reviewing and synthesizing of the scientific literatures to identify, select and evaluate the studies related to Southeast Asia on EE in HLIs. The final part identifies the main concern of future research.

\section{Methodology}

The method used to obtain the articles related to the outcome of EE in HLIs in Southeast Asia is discussed. The primary resources for this study were peer-reviewed journals from the Web of Science and Scopus database. The PRISMA approach was used to carry out systematic reviews like eligibility criteria and exclusions, process review like identification, screening and eligibility steps. These were followed by data abstraction and analysis of articles.

\subsection{Research Design}

A systematic review was outlined based on important criteria from the PRISMA checklist. The PRISMA Statement allowed the search of terms related to EE at HLIs in Southeast Asia. This was to ascertain whether appropriate measures were taken to minimize bias in the design and revision response.

\subsection{Resources}

The review covered two main journal databases: Scopus and the Web of Science (WoS). Scopus is the largest abstract and citation database of peer-reviewed literature: scientific journals, books and conference proceedings from 5000 publishers worldwide. Meanwhile, WoS is the second database used in this review. WoS is a well-established database journals covering over 256 disciplines including subjects related to educational studies, social sciences, entrepreneurship, economic, development and planning.

\subsection{Eligibility and Exclusion Criteria}

Some eligibility criteria and exceptions were determined. First, only journal articles with empirical data were selected, while article reviews, book series, books, chapters in books and conference papers were excluded. Secondly, to avoid confusion and difficulty in translating, search efforts focused only on articles published in English. Thirdly, with regard to the timeline, only 10-year-ranged articles were selected (between 2009 and 2018), whereby the time was sufficient enough to see the evolution of research and related publications. As the review process focused on EE in HLIs, indexed articles in social science-based indexes were selected, which means articles published in the hard science index (Science Citation Indexed Expanded) were excluded. Finally, in line with the aim of this study that focused on higher learning or universities in Southeast Asia, the articles selected were only concentrated in the respective countries.

\subsection{Systematic Review Process}

There were four stages in the systematic review process that was conducted in January 2019. The first stage was to identify the keywords used for the search process. Relying on previous studies and thesaurus, similar keywords related to EE and HLIs were used. The search was conducted using the following terms for Scopus database: TITLE-ABS-KEY ("entrepreneurship education" OR "entrepreneurial education" OR "entrepreneurial learning") AND TITLE-ABS-KEY ("higher learning" OR "higher education" OR tertiary OR university) AND TITLE-ABS-KEY ("potential entrepreneur" OR student OR graduate). While for the WoS database, the following terms were used: TS= ("entrepreneurship education" OR "entrepreneurial education" OR "entrepreneurial learning") AND TS= ("higher education" OR "higher learning" OR tertiary OR university) AND TS= ("potential entrepreneur" OR student OR graduate).

At this stage, after careful screening, 250 duplicated articles were deleted. The second stage was screening and out of 1184 eligible articles reviewed, 1093 articles were removed. The third stage was the eligibility, whereby full articles were accessed. After a careful examination, a total of 23 articles were excluded since they did not focus on the output of EE, they were conceptual papers, and they did not focus on Southeast Asian countries. The final stage of review indicated a total of 68 articles were used for qualitative analysis (Figure 1). 


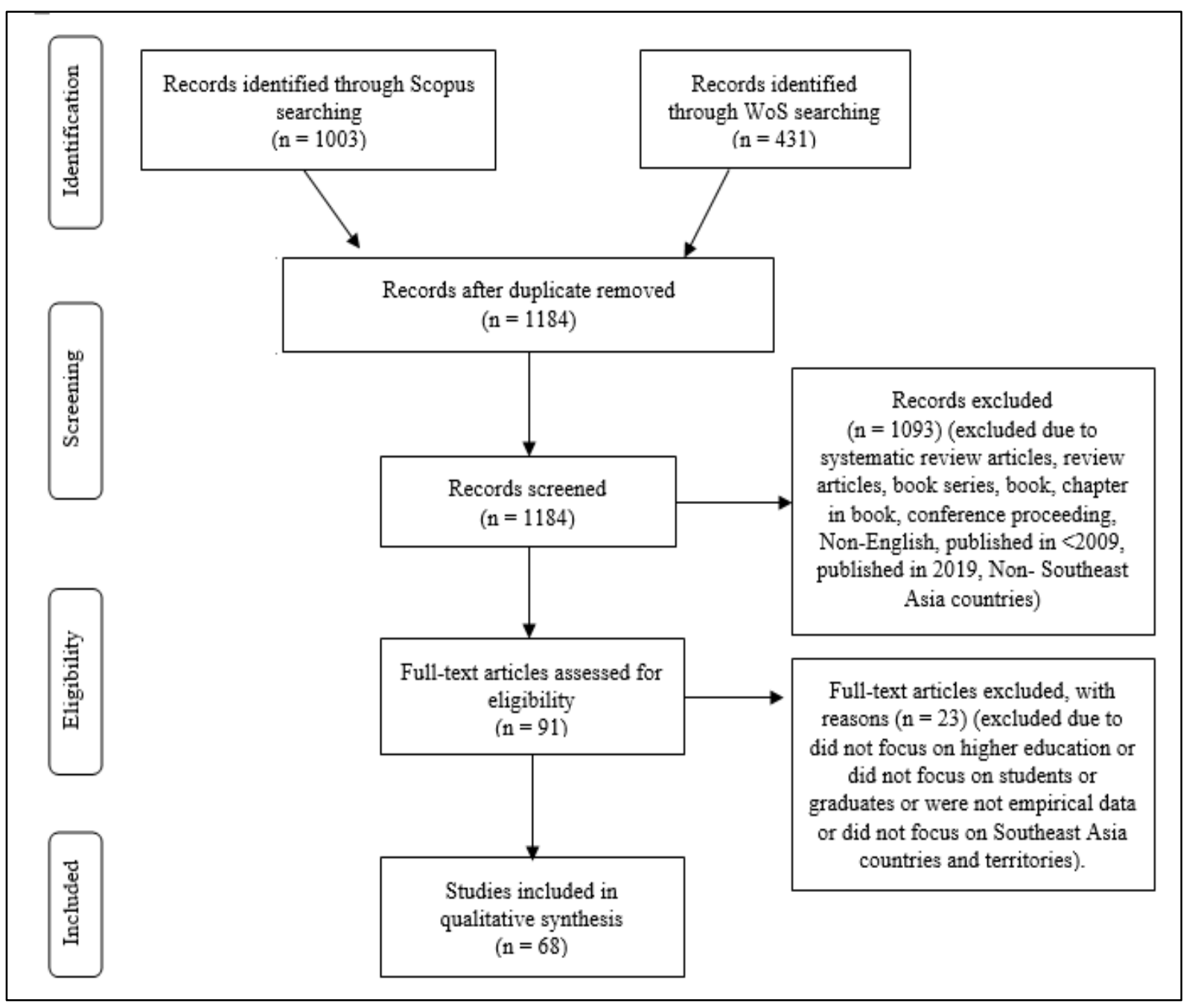

Figure 1. PRISMA Flowchart

\subsection{Data Abstraction and Analysis}

The remaining articles were evaluated and analyzed. Efforts were focused on specific studies that responded to formulated questions. The data was extracted by reading the abstracts first, then the full articles (in depth) to identify the appropriate themes. Qualitative analysis was done by using content analysis to identify themes related to EE in HLIs in Southeast Asia.

\section{Results \& Discussion}

This present study shows an overview of 68 articles that met the criteria of this systematic review. Figure 2 illustrates a varying number of publications that exists for the ten years period of 2009 to 2018 . At the beginning of the period, only one article was published and two studies were published in 2010 and 2011. The figure increased to reach to about six studies in 2012 and dipped slightly to five studies in 2013 and 2014. The following year, in 2015, the figure grew up to seven studies after which, it rose significantly to reach as high as 18 studies in 2018. Overall, the number of publications of EE in HLIs increased over the past decade in Southeast Asia. Thus, it can be visibly seen that the trend of EE studies in higher learning is growing and gaining more attention by scholars. This is in line with entrepreneurship course offerings by colleges and universities that have exceeded three thousand worldwide (Kuratko \& Morris, 2017). Furthermore, the policies of the governments that promote $\mathrm{EE}$ as a way to stimulate economic growth and reduce unemployment rate among graduates also contributed to this growth trend. 


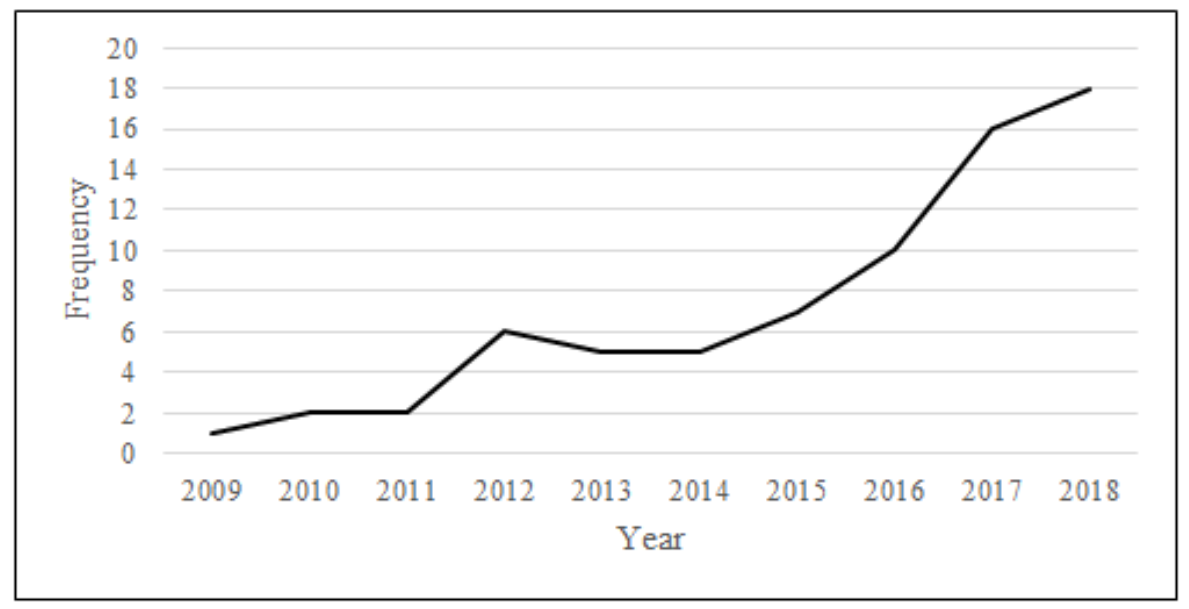

Figure 2. The Trends of Entrepreneurship Education Studies in Southeast Asia

The aims of this study were to systematically analyze the existing literatures on the outcome of EE in HLIs in Southeast Asia. The outcome should be completely determined at the beginning of entrepreneurial learning to ensure that the results were clearly accessible. Learning outcome refers to what a learner should know, understand or able to show after the completion of the learning process (Watson, 2002). In terms of the countries, Malaysia has the majority percentage (57.36\%, 39 articles) of articles contributing to the field, followed by Indonesia (39.70\%, 27 articles), the Philippines and Singapore, which published $1.47 \%$ (one article) respectively. This review resulted in sixth main themes, entrepreneurial attitudes, entrepreneurial motivation, entrepreneurial knowledge and skills, entrepreneurial intention, entrepreneurial competency and business start-up. Table 1 provides a comprehensive analysis of the current outcome of EE in HLIs in Southeast Asian countries. 
Table 1. Outcome of Entrepreneurship Education

\begin{tabular}{|c|c|c|c|c|c|}
\hline Attitude & Motivation & Knowledge \& Skills & Competency & Intention & Business Start up \\
\hline $\begin{array}{l}\text { Handrimurtjahjo et al. (2015) } \\
\text { Kusmintarti et al. (2018) Mamun et al. } \\
\text { (2017c) } \\
\text { Nuryanti (2016) } \\
\text { Othman \& Ab Wahid (2014) } \\
\text { Pihie \& Bagheri (2012) }\end{array}$ & $\begin{array}{l}\begin{array}{l}\text { Hutagalung at al. } \\
\text { (2017) } \\
\text { Syam et al. (2018) }\end{array}\end{array}$ & $\begin{array}{l}\text { Abdullah et al. (2017) } \\
\text { Ahmad et al. (2014) } \\
\text { Chew et al. (2016) } \\
\text { Din et al. (2016) } \\
\text { Din et al. (2017) } \\
\text { Ghadas et al. (2014) } \\
\text { Ibrahim et al. (2018) } \\
\text { Johari et al. (2016) } \\
\text { Larso \& Saphiranti (2016) } \\
\text { Sudrajat et al. (2018) } \\
\text { Sendouw et al. (2018) } \\
\text { Suparno \& Saptono (2018) } \\
\text { Sudarmiatin et al. (2017) } \\
\text { Sumarno \& Suarman } \\
\text { (2017) } \\
\text { Velasco (2013) } \\
\text { Zain et al. (2013) }\end{array}$ & $\begin{array}{l}\text { Bagheri \& Pihie (2011) } \\
\text { Bagheri \& Pihie (2013) } \\
\text { Ghina et al. (2017) } \\
\text { Haris et al. (2018) } \\
\text { Kusmintarti et al. (2016) } \\
\text { Othman et al. (2012) Rusok et al. } \\
\text { (2017) }\end{array}$ & $\begin{array}{l}\text { Azis et al. (2018) } \\
\text { Chew et al. (2018) } \\
\text { Eryanto et al. (2018) } \\
\text { Gafar et al. (2015) } \\
\text { Ghadas et al. (2012) } \\
\text { Hamzah et al. (2016) } \\
\text { Ismail et al. (2018) } \\
\text { Koe et al. (2018) } \\
\text { Kusmintarti et al. (2016) } \\
\text { Kusumojanto et al. (2017) } \\
\text { Looi (2018) } \\
\text { Mamun et al. (2017a) } \\
\text { Mohamad et al. (2015) } \\
\text { Mohamed et al. (2012) } \\
\text { Mohd et al. (2015) } \\
\text { Mustapha \& Selvaraju (2015) } \\
\text { Ngah et al. (2017) } \\
\text { Nuringsih \& Puspitowati } \\
\text { (2017) } \\
\text { Ooi \& Nasiru (2015) } \\
\text { Pihie \& Bagheri (2013) } \\
\text { Pihie (2009) } \\
\text { Purwana et al. (2017) } \\
\text { Ramayah et al. (2012) } \\
\text { Riyadi et al. (2018) } \\
\text { Ruswanti (2016a) } \\
\text { Shahverdi et al. (2018) } \\
\text { Utami (2017) } \\
\text { Zainuddin \& Ismail (2011) } \\
\text { Zainuddin \& Rejab (2010) } \\
\text { Zainuddin et al. (2012) }\end{array}$ & $\begin{array}{l}\text { Aldianto et al. (2018) } \\
\text { Anuar et al. (2013) } \\
\text { Darmanto \& Yuliari } \\
\text { (2018) } \\
\text { Ho et al. (2014) } \\
\text { Mamun et al. (2017b) } \\
\text { Nasirun et al. (2017) } \\
\text { Othman \& Mydin (2010) }\end{array}$ \\
\hline
\end{tabular}




\subsection{Entrepreneurial Attitude}

There are six studies that measured entrepreneurial attitude as their outcome (Handrimurtjahjo et al., 2015; Kusmintarti et al., 2018; Mamun et al., 2017c; Nuryanti, 2016; Othman \& Ab Wahid, 2014; Pihie \& Bagheri, 2012). All studies used quantitative approach and their samples were students in tertiary education. Several studies identified the entrepreneurial characteristics that significantly contributed towards the effectiveness of EE among students, such as innovation, creativity, self-confidence, risk-thinking, need for achievement and locus of control.

\subsection{Entrepreneurial Motivation}

A total of two studies focused on motivation as the outcome of EE. In this context, the scholars used the multiple technique of data collection like observation, questionnaires and documentation (Syam et al., 2018), and questionnaire (Hutagalung et al., 2017). The result of this study indicated that the characteristic of EE is important, and it significantly influences entrepreneurial motivation (Hutagalung et al., 2017; Syam et al., 2018).

\subsection{Entrepreneurial Knowledge and Skills}

There are 16 studies that concentrated on entrepreneurial knowledge and skills as the output of EE. A few studies highlighted that students have great potentials to become successful entrepreneurs if they have good knowledge and adequate entrepreneurial skills (Sudrajat et al., 2018; Suparno et al., 2018; Sendouw et al., 2018; Sudarmiatin et al., 2017). Kusmintarti et al. (2018) said that students who intend to create new business must have entrepreneurship skills, technical skills and management skills. The result showed financial literacy (Suparno et al., 2018), computing skills (Ibrahim et al. 2018) and soft skills (Johari et al., 2016) positively influence entrepreneurial skills (Suparno et al., 2018).

\subsection{Entrepreneurial Intention}

A total of 30 studies focused on entrepreneurial intention as the outcome of EE. Most of the studies (27 articles) used the quantitative approach and 3 studies used mixed method as their research design. In this context, some scholars adapted the Theory of Planned Behavior as their guideline (Shahverdi et al., 2018; Utami, 2017; Kusumojanto et al., 2017; Zainuddin \& Ismail, 2011). The findings showed attitude (Riyadi et al., 2018; Utami, 2017; Kusumojanto et al., 2017; Mustapha \& Selvaraju, 2015; Zainuddin \& Ismail, 2011; Ruswanti, 2016a; Pihie, 2009), subjective norm (Kusumojanto et al., 2017; Mustapha \& Selvaraju, 2015), and perceived behavioral control (Kusumojanto et al., 2017; Ramayah et al., 2012; Pihie, 2009) positively affect entrepreneurial intentions. However, the subjective norm was found to be an insignificant predictor of entrepreneurial intention (Kusumojanto et al., 2017; Zainuddin \& Ismail, 2011).

Besides that, several studies measured entrepreneurial self-efficacy (Utami, 2017; Phie \& Bagheri, 2013; Zainuddin \& Ismail, 2011; Zainuddin \& Rejab, 2010), self-regulation (Looi, 2018; Phie \& Bagheri, 2013), entrepreneurial aspiration (Pihie, 2009), entrepreneurial knowledge (Ruswanti, 2016a), entrepreneurial skills (Hamzah et al., 2016), role model and role played by the community (Ooi \& Nasiru, 2015) to predict the entrepreneurial intentions among students. Interestingly, there are five studies which proved that entrepreneurial self-efficacy (Darmanto et al., 2018; Shahverdi et al., 2018; Din et al., 2017) and entrepreneurial attitudes (Kusumojanto et al., 2017; Hutagalung, 2017) positively affect EE and entrepreneurial intention.

\subsection{Entrepreneurial Competency}

Seven studies were concentrated on entrepreneurial competency as the outcome of EE, while four studies used quantitative approaches (Haris et al., 2018; Rusok et al., 2017; Bagheri \& Pihie, 2013; Othman et al., 2012), and three studies used qualitative approaches (Ghina et al., 2017; Kusumastuti et al., 2016; Bagheri \& Pihie, 2011). In this context, several studies assessed the entrepreneurial competency through (i) entrepreneurial characteristics namely risk propensity, self-efficacy, and need for achievement (Rusok et al., 2017), (ii) entrepreneurial skills namely thinking and problem solving, leadership skills, analysis, preparing business plan, motivation, networking and adaptability (Kusumastuti et al., 2016; Rusok et al., 2017; Bagheri and Pihie, 2013), and (iii) entrepreneurial knowledge (Othman et al., 2012). Furthermore, entrepreneurial capabilities are also used to measure competency among students in entrepreneurship (Othman et al., 2012; Bagheri \& Pihie, 2011).

\subsection{Business Start-Up}

A total of seven studies focused on business start-up as the outcome of entrepreneurial learning. The majority of the studies used quantitative approach (Darmanto \& Yuliari, 2018; Aldianto et al., 2018; Nasirun et al., 2017; Ho et al., 2014; Othman \& Mydin, 2010), while only one study used qualitative approach (Anuar et al., 2013). Business start-up refers to entrepreneurial behavior or entrepreneurial engagement of students to create or start the business activities (Nasirun et al., 2017; Mamun et al., 2017; Ho et al., 2014), entrepreneurial action in starting a business (Darmanto \& Yuliari 2018; Anuar et al., 2013), and courage and readiness to face potential risks (Aldianto et al., 2018). Besides, there are two factors of entrepreneurial behaviors by Othman and Mydin (2010), namely cognitive and non-cognitive. The cognitive entrepreneurial behavior consists of an individual's 
knowledge, goal development, planning and problem solving. Meanwhile, the non-cognitive entrepreneurial behavior, namely external control factor, controlled by something, internal self-control, tolerance toward ambiguity and self-evaluation.

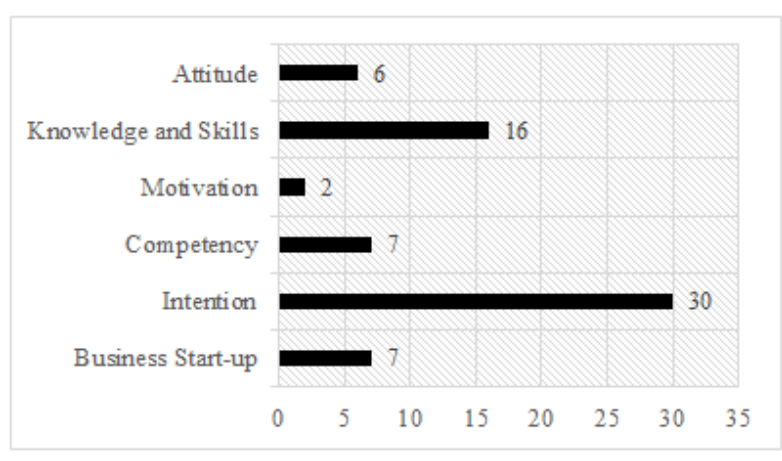

Figure 3. The Outcome of Entrepreneurship Education

Figure 3 illustrates the distribution of themes of EE outcome in higher learning between the year of 2009 and 2018 in Southeast Asia. The most extensive study conducted by academic journals was entrepreneurial intention (44.12\%, 30 studies), followed by entrepreneurial knowledge and skills (23.53\%, 16 studies). Next is entrepreneurial competency and business start-up which indicated $10.29 \%$ (7 studies) respectively. There is $8.83 \%$ (6 studies) for entrepreneurial attitude, while the least studies is on entrepreneurial motivation (2.94\%, 2 studies). Therefore, for over one decade, the studies on entrepreneurial intention have been dominated as the outcome of EE in Southeast Asia. This result is in line with Nabi et al. (2017) who found that $51 \%$ articles on $\mathrm{EE}$ outcome focused on entrepreneurial intention. Based on the reviews of entrepreneurial intention, there are two aspects that past studies emphasized, namely (i) to develop antecedents of intention (entrepreneurial characteristics, motivation, knowledge, etc.) and (ii) to find support of three dimensions of the Theory of Planned Behavior. Therefore, the study of entrepreneurial intentions is growing because of the aim to understand what drives students to choose entrepreneurship as a career.

Furthermore, majority of the scholars agree to the effectiveness of EE in HLIs. Several studies identified that entrepreneurial characteristics significantly contribute to the effectiveness of EE among students, including innovation, creativity, self-efficacy, risk-thinking, need for achievement and locus of control (Darmanto \& Yuliari, 2018; Din et al., 2017; Larso \& Saphiranti, 2016). Besides that, students have great potentials to become successful entrepreneurs if they have entrepreneurial knowledge, entrepreneurial skills, technical skills and management skills (Sudrajat et al., 2018; Suparno et al., 2018; Kusmintarti et al., 2018). However, three articles found mixed results namely the ability of preparing business plan, self-efficacy (Din et al., 2017), subjective norm (Zainuddin \& Ismail, 2011) and opportunity skills (Koe et al., 2018) as not significant. The findings by Pihie (2009) showed that students who are exposed to entrepreneurship education in universities will have more positive outcomes toward entrepreneurship career. Therefore, entrepreneurial learning is important in the higher education to enhance entrepreneurial capabilities, intention and behaviors, before starting a business.

This finding has shown that all the themes of the entrepreneurship education outcome are significant to develop students and potential entrepreneurs towards entrepreneurship. However, some articles did not clearly state the goals of EE based on their institutions. Supposedly, scholars need to understand the goals of EE in their universities. There are three commonly used approaches to entrepreneurial education (Heinonen \& Hytti, 2010, O'Connor 2013). Education about entrepreneurship means an approach that provides general understanding about entrepreneurship. Education for entrepreneurship means providing an understanding of the knowledge and skills required by entrepreneurs. Education through entrepreneurship means a process-based approach and experience where students get through the process of real entrepreneurship learning. Indirectly, the learning outcomes of EE are related to the approach or pedagogy used by the instructors. Therefore, the teaching approaches and curriculum used in an institution play important roles in ensuring the goal of EE to be achieved.

\section{Recommendations for Future Research}

Based on the 68 studies that were reviewed, there are some aspects that require attention. Firstly, entrepreneurial intention is considered a central concept in explaining behavior. Most of the studies only examine the students' entrepreneurship intentions rather than their actual behaviors. In addition, studies that explain relationship between intention and behavior are very limited. It is suggested that the future researches should concentrate on transition of intention to behavior. Besides that, most studies rely on electronic keyword search because this technique is recognized as the best search method for a systematic review. However, reference searching can be considered as another technique. Reference searching examines the list of references in the selected articles for other articles. This technique is appropriate when researchers face challenges in finding relevant information, thus checking the list of potential references can reduce the risk of losing relevant information (Horsley et al., 2011).

\section{Conclusions}

This study presented a systematic review of existing literature on the outcome of EE in HLIs by reviewing the latest ten-year published corpus in Southeast Asian 
countries. A rigorous review sourced from two databases namely Scopus and WoS resulted in finding 68 articles related to the field. This review provides scholars or policy makers with the views on the effectiveness of entrepreneurship education in higher learning. This shows that the trend of EE studies in higher learning is growing and gaining attention from scholars. The outcome of EE could be visibly seen whether it has positive effects or otherwise, in developing the potentials of students as entrepreneurs. This review resulted in sixth main themes, entrepreneurial attitudes, entrepreneurial motivation, entrepreneurial knowledge and skills, entrepreneurial intention, entrepreneurial competency and business start-up. Furthermore, majority of the scholars have conducted studies on entrepreneurial intentions (44.12\%) over the past ten years. On other hand, only $10.30 \%$ of these articles touched on business start-ups. Therefore, the curriculum developed by the institution must be in line with the outcome of entrepreneurship education.

\section{REFERENCES}

[1] Abdullah, S., Rahim, M.S., \& Zakaria, N. (2017). Riding the practice of technopreneur development: Innovative entrepreneurial teaching and learning in institutes of higher learning. International Journal of Economic Research, 14 (15), 213-225.

[2] Ahmad, S.Z., Ismail, M.Z., Buchanan, F.R. (2014). Examining the entrepreneurship curriculum in Malaysian polytechnics. International Journal of Management Education, 12 (3), 397-406.

[3] Aldianto, L., Anggadwita, G., \& Umbara, A.N. (2018). Entrepreneurship education program as value creation: Empirical findings of universities in Bandung, Indonesia. Journal of Science and Technology Policy Management, 9 (3), 296-309.

[4] Anuar, A., Nasir, I.N.M., Rahman, F.A., Sadek, D.M. (2013). Barriers to start-up the business among students at tertiary level: A case study in northern states of peninsular Malaysia. Asian Social Science, 9 (11), 291-299.

[5] Azis, M., Haeruddin, M.I.M., \& Azis, F. (2018). Entrepreneurship education and career intention: The perks of being a woman student. Journal of Entrepreneurship Education, 21(1), 1-10.

[6] Bagheri, A., \& Pihie, Z.A.L (2013). Role of university entrepreneurship programs in developing students' entrepreneurial leadership competencies: Perspectives from Malaysian undergraduate students. Journal of Education for Business, 88 (1), 51-61.

[7] Bagheri, A., \& Pihie, Z.A.L. (2011). On becoming an entrepreneurial leader: A focus on the impacts of university entrepreneurship programs. American Journal of Applied Sciences, 8 (9), 884-892.

[8] Bechard, J.P. \& Gregoire, D. (2005). Entrepreneurship education research revisited: The case of higher education.
Academy of Management Learning and Education, 4(1), 22-43.

[9] Chew, L.M., Hoe, L.S., Kim, T.C., \& Kiaw, L.W.Y. (2016). Self-perceived entrepreneurship skills for undergraduates of private university in Malaysia. American Journal of Applied Sciences, 13 (6), 715-725.

[10] Chew, L.M., Hoe, L.S., Kim, T.C., \& Kiaw, L.W.Y. (2018). The influence of entrepreneurship education and family background on students' entrepreneurial interest in nutritious traditional food startups in Indonesia. International Journal of Engineering and Technology, 7(4), 118-122.

[11] Darmanto, S., \& Yuliari, G. (2018). Mediating role of entrepreneurial self-efficacy in developing entrepreneurial behavior of entrepreneur students. Academy of Entrepreneurship Journal, 24 (1), 1-14.

[12] Din, B.H., Anuar, A.R., \& Usman, M. (2016). Does the entrepreneurship education matters in enhancing entrepreneurial skill among students in Malaysian public universities? International Review of Management and Marketing, 6 (7), 107-111.

[13] Din, B.H., Aziz, A.R., Anuar, A.R., \& Usman, M. (2017). Youth entrepreneurship development in Malaysian higher learning institutions. International Journal of Economic Research, 14 (16), 447-454.

[14] Dumitrache, V. \& Raileanu, S.M. (2014). The role of business education provided through lifelong learning in enhancing profesional competencies. Amfiteatru Economic Journal, 16(37), 874-884.

[15] Eryanto, H., \& Swaramarinda, D.R. (2018). Influence ability, perception of change and motivation to intention of entrepreneurship: Overview of analysis in students of faculty of economics universitas negeri Jakarta. Journal of Entrepreneurship Education, 21 (3), 1-10.

[16] Fayolle, A. \& Gailly, B. (2008). From craft to science Teaching models and learning processes in entrepreneurship education. Journal of European Industrial Training, 32: 569-593.

[17] Fayolle, A. (2013). Personal views on the future of entrepreneurship education. Journal Entrepreneurship \& Regional Development 25(7), 692-701.

[18] Gafar, M., Yusoff, W.F.W., Kasim, R., \& Martin, D. (2015). Attitude to business reality, perceived value creation and subjective norms: How they impact on students of higher learning institutions' self-employment intentions in Malaysia. Mediterranean Journal of Social Sciences, 6(1), 186-196.

[19] Ghadas, Z.A.A., Muslim, H., \& Hamid, Z. (2012). Law students and entrepreneurship: A study on the relationship between involvement in entrepreneurship programs and interest to be entrepreneurs with special reference to IIUM. Australian Journal of Basic and Applied Sciences, 6 (11), 252-257.

[20] Ghadas, Z.A.A., Muslim, H., \& Hamid, Z. (2014). Legal eagle entrepreneurship education for law Students: Special reference to international Islamic university Malaysia. Pertanika Journal of Social Science and Humanities, 22 (1), 83-93. 
[21] Ghina, A., Simatupang, T.M., \& Gustomo, A. (2017). The relevancy of graduates' competencies to the effectiveness of entrepreneurship education: A case study at SBM ITB-Indonesia. Journal of Entrepreneurship Education, 20 (1), 1-24.

[22] Gutierrez, G.J. \& Baquero, G.J.E. (2017). New cross-proposal entrepreneurship and innovation in educational programs in third level (tertiary) education. Contaduria y Administracion, 62(1), 239-261.

[23] Hamzah, H., Yahya, Z., Sarip, A.G., \& Adnan, Y.M. (2016). Impact of entrepreneurship education programme (EEP) on entrepreneurial intention of real estate Graduates. Pacific Rim Property Research Journal, 22 (1), 17-29.

[24] Handrimurtjahjo, A.D., Setiadi, N.J., \& Kuncoro, E.A. (2015). The role of entrepreneurship education in forming students' entrepreneurial attitudes. Advanced Science Letters, 21(4), 596-600.

[25] Haris, R., Haryoko, S., Malago, J.D., \& Pertiwi, N. (2018). The competence of young entrepreneur candidate in university, Indonesia. Journal of Entrepreneurship Education, 21 (3), 1-9.

[26] Ho, Y.P., Low, P.C., \& Wong, P.K. (2014). Do university entrepreneurship programs influence students' entrepreneurial behavior? An empirical analysis of university. Advances in the Study of Entrepreneurship, Innovation, and Economic Growth, 24, 65-87.

[27] Horsley, T., Dingwall, O., \& Sampson, M. (2011). Examining reference lists to find relevant studies for systematic reviews. Cochrane Database of Systematic Reviews, 8, 1-25.

[28] Hutagalung, B., Dalimunthe, D.M.J., Pambudi, R., Hutagalung, A.Q., Muda, I. (2017). The effect of entrepreneurship education and family environment towards students' entrepreneurial motivation. International Journal of Economic Research, 14 (20), 331-348.

[29] Ibrahim, H.I., Jaaffar, A.H., Zulkafli, A.H., \& Mohammad Shah, K.A. (2018). Investigating Work Integrated Learning (WIL) outcomes and motivation to learn. Journal of Engineering and Applied Sciences, 13 (6), 1316-1319.

[30] Ismail, A.B. T., Sawang, S., \& Zolin, R. (2018). Entrepreneurship education pedagogy: teacher-student-centred paradox. Education + Training, 60(2), 168-184.

[31] Johari, N., Kahar, R., Habil, H., \& Abdul Hamid, S.A. (2016). Entrepreneurship education: Incorporation of soft skills through hands-on experience. Man in India, 96 (1-2), 161-171.

[32] Karimi, S., Biemans, J.A., Lans, T., Chizari, M. \& Mulder, M. (2014). The impact of entrepreneurship education: A study of Iranian students' entrepreneurial intentions and opportunity identification. Journal of Small Business Management, 5(3), 299-307.

[33] Katz, J. A. (2003). The chronology and intellectual trajectory of American entrepreneurship education: 1876-1999. Journal of Business Venturing 18(2), 283-300.

[34] Koe, W.L., Krishnan, R., \& Utami, S. (2018). The influence of entrepreneurial skills on business start-up intention among Bumiputra students. Journal of Advanced Manufacturing Technology, 12 (2), 53-64.

[35] Kuratko, D.F. \& Morris, M.H. (2017). Examining the future trajectory of entrepreneurship. Journal of Small Business Management 56 (1), 12-19.

[36] Kusmintarti, A., Anshori, M.A., Sulasari, A., \& Ismanu, S. (2018). Student's entrepreneur profile: A cluster of student's entrepreneurial characteristics. Journal of Entrepreneurship Education, 21 (1S), 1-12.

[37] Kusmintarti, A., Thoyib, A., Maskie, G., \& Ashar, K. (2016). Entrepreneurial characteristics as a mediation of entrepreneurial education influence on entrepreneurial intention. Journal of Entrepreneurship Education, 19 (1), 24-37.

[38] Kusumastuti, D., Narimawati, U., \& Pujihartanti, E. (2016). Developing entrepreneurship competency and economic added value among the graduates (study at private universities in Indonesia). International Journal of Economic Research, 13 (8), 3551-3569.

[39] Kusumojanto, D.D., Soetjipto, B.E., Murwani, F.D., \& Sunaryanto (2017). The effect of entrepreneurship education, parents' role, and self-efficacy on students' entrepreneurship intention mediated by entrepreneurship attitudes. International Journal of Applied Business and Economic Research, 15 (19), 265-277.

[40] Larso, D., \& Saphiranti, D. (2016). The role of creative courses in entrepreneurship education: A case study in Indonesia. International Journal of Business, 21 (3), 216-225.

[41] Looi, K.H. (2018). Self-direction as potential predictor of undergraduates' entrepreneurial intentions. Journal for International Business and Entrepreneurship Development, 11 (3), 243263.

[42] Mamun, A.A., Fong, S.P., \& Nawi, N.B.C. (2017c). Entrepreneurship education and students' career choice. Advanced Science Letters, 23 (4), 2954-2957.

[43] Mamun, A.A., Nawi, N.B.C., Mohiuddin, M., Shamsudin, S.F.F.B., \& Fazal, S.A. (2017b) Entrepreneurial intention and startup preparation: A study among business students in Malaysia. Journal of Education for Business, 92 (6), 296-314.

[44] Mamun, A.A., Shamsudin, S.F.F.B., Nawi, N.B.C., Nasi, N.A.B.M., \& Zakaria, M.N.B. (2017a). Entrepreneurial education service quality, entrepreneurial intention, and 'key performance indicators' of entrepreneurship education policies in Malaysia. Advanced Science Letters, 23 (9), 8204-8209.

[45] Mohamad, N., Lim, H.E., Yusof, N., \& Soon, J.J. (2015). Estimating the effect of entrepreneur education on graduates' intention to be entrepreneurs. Education and Training, 57 (8-9), 874-890.

[46] Mohamed, Z., Rezai, G., Shamsudin, M.N., \& Mahmud, M.M. (2012). Enhancing young graduates' intention towards entrepreneurship development in Malaysia. Education and Training, 54 (7), 605-618.

[47] Mohd, N., Maat, S.M., \& Mat, S.C. (2015). A study on entrepreneurial intention among engineering technology 
students. Mediterranean Journal of Social Sciences, 6 (4), 348-355.

[48] Mustapha, M., \& Selvaraju, M. (2015). Personal attributes, family influences, entrepreneurship education and entrepreneurship inclination among university students. Kajian Malaysia, 33, 155-172.

[49] Nabi, G., Linan, F., Alain, F. \& Walmsley, A. (2017). The impact of entrepreneurship education in higher education: A systematic review and research agenda. Academy of Management Learning and Education, 16(2), 277-299.

[50] Nasirun, N., Noor, S.M., Yusoff, R.Z., \& Othman, A.A. (2017). Student engagement, student interactions and student satisfaction in blended leaning: A case of entrepreneurship education. Advanced Science Letters, 23(8), 7952-7955.

[51] Ngah, R., \& Osman, C.A. (2017). Entrepreneurship education and entrepreneurial learning on students' entrepreneurial intention in Malaysia: Investigating the role of entrepreneurial self-efficacy. Advanced Science Letters, 23(8), 7129-7533.

[52] Nuringsih, K., \& Puspitowati, I. (2017). Determinants of eco entrepreneurial intention among students: Study in the entrepreneurial education practices. Advanced Science Letters, 23 (8), 7281-7284.

[53] Nuryanti, B.L. (2016). The impact of active learning on entrepreneurial mindset. Man in India, 96 (12), 4861-4870.

[54] Ooi, Y.K., \& Nasiru, A. (2015). Entrepreneurship education as a catalyst of business start-ups: A study on Malaysian community college students. Asian Social Science, 11 (18), 350-363.

[55] Othman, N., \& Mydin, K.F. (2010). Entrepreneurship behaviour amongst Malaysian university students. Pertanika Journal of Social Science and Humanities, 18(1), 23-32.

[56] Othman, N., \& Wahid, H.A. (2014). Social entrepreneurship among participants in the students in free enterprise program. Education and Training, 56, 852-869.

[57] Othman, N., Hashim, N., \& Wahid, H.A. (2012). Readiness towards entrepreneurship education: Students and Malaysian universities. Education and Training, 54 (8), 697-708.

[58] Othman, N., Othman, N.H., \& Ismail, R. (2012). Impact of globalization on trends in entrepreneurship education in Higher Education Institutions. International Journal of Trade, Economics and Finance 3(4), 267-271.

[59] Pihie, Z.A.L. (2009). Entrepreneurship as a career choice: An analysis of entrepreneurial self-efficacy and intention of university students. European Journal of Social Sciences, 9 (2), 338-349.

[60] Pihie, Z.A.L., \& Bagheri, A. (2012). An exploratory study of entrepreneurial attributes among Malaysian university students. Life Science Journal, 9 (3), 2358-2365.

[61] Pihie, Z.A.L., \& Bagheri, A. (2013). Students' entrepreneurial regulation and intention to become an entrepreneur: A comparison between public and private universities. South African Journal of Business Management, 44 (4), 25-32.
[62] Purwana, D., Suhud, U., \& Rahayu, S.M. (2017) Entrepreneurial intention of secondary and tertiary students: Are they different? International Journal of Economic Research, 14 (18), 69-81.

[63] Ramayah, T., Ahmad, N.H., \& Fei, T.H.C. (2012). Entrepreneur education: Does prior experience matter? Journal of Entrepreneurship Education, 15, 65-82.

[64] Riyadi, Kholil, A., \& Jumhur, A.A. (2018). Factors affecting the entrepreneurship intention motorcycle workshop. Journal of Entrepreneurship Education, 21 (4)

[65] Rusok, N.H.M., Kumar, N., \& Ahmed, A.R. (2017). The effect of entrepreneurship education on entrepreneurial competencies. International Journal of Applied Business and Economic Research, 15 (15), 433-455.

[66] Ruswanti, E. (2016). Entrepreneurship knowledge, training home industry, and attitude towards entrepreneurial intention entrepreneurship. International Journal of Applied Business and Economic Research, 14 (5), 2803-2816.

[67] Sendouw, R.H.E., Kairupan, S.B., \& Mege, R.A. (2018) Applied entrepreneurship education at University of Manadonorth Sulawesi Indonesia. International Journal of Engineering and Technology, 7(3), 282-285.

[68] Shahverdi, M., Ismail, K., \& Qureshi, M.I. (2018). The effect of perceived barriers on social entrepreneurship intention in Malaysian universities: The moderating role of education. Management Science Letters, 8 (5), 341-352.

[69] Sudarmiatin, Soetjipto, B.E., Handayati, P., Suharto, \& Hidayat, R. (2017). Experiential learning: An alternative model of entrepreneurship learning in higher education. International Journal of Applied Business and Economic Research, 15 (19), 243-252.

[70] Sudrajat, J., Rahman, M.A., Guzman, G.A., Ricky, M.Y., \& Sasongko, A.H. (2018). Innovation of entrepreneurship learning with business model canvas game. International Journal of Entrepreneurship, 22(3), 1-12.

[71] Sumarno, S., \& Suarman. S. (2017). Development of technopreneurship- based entrepreneurship education for students at Universitas Riau, Indonesia. International Journal of Economic Research, 14 (12), 65-74.

[72] Suparno, \& Saptono, A. (2018). Entrepreneurship education and its influence on financial literacy and entrepreneurship skills in college. Journal of Entrepreneurship Education, 21 (4), 1-11.

[73] Syam, A., Hasbiah, S., Yunus, M., \& Akib, H. (2018). Determinants of entrepreneurship motivation for students at educational institution and education personnel in Indonesia. Journal of Entrepreneurship Education, 21 (2), 1-12.

[74] Utami, C.W. (2017). Attitude, subjective norms, perceived behavior, entrepreneurship education and self-efficacy toward entrepreneurial intention university student in Indonesia. European Research Studies Journal, 20 (2), 475-495.

[75] Velasco, A.L. (2013). Entrepreneurship education in the Philippines. DLSU Business and Economics Review, 6(6), 168-177.

[76] Watson, P. (2002). The role and integration of learning outcomes into the educational process. Active Learning in 
Higher Education, 3(3), 205-219.

[77] Zain, S.M., Basri, N.E.A., Mahmood, N.A., Basri, H., Yaacob, M., \& Ahmad, M. (2013). Innovation in sustainable education and entrepreneurship through the UKM recycling center operations. International Education Studies, 6 (6), 168-177.

[78] Zainuddin, M.N., \& Ismail, H. (2011). Push and pull factor in an entry into an employment route: A study of nurtured entrepreneurship students. International Journal of Entrepreneurship and Small Business, 13 (4), 469-498.

[79] Zainuddin, M.N., \& Rejab, M.R.M. (2010). Assessing "ME generation's" entrepreneurship degree programmes in Malaysia. Education and Training, 52 (6), 508-527. 